\title{
The Sanctification of Mary
}

\section{Summa Halensis and the status quaestionis prior to William of Ware and John Duns Scotus}

\begin{abstract}
This article examines the early thirteenth century Franciscan position on the Immaculate Conception. Following a presentation of the basic argument taken from Summa Halensis, we show how these arguments support the denial of the Immaculate Conception, while they defend her sanctification in utero. The argument concludes with a consideration of how these early foundations that ground the denial actually provide the conditions for the possibility of the later, definitive defense of the Marian prerogative. Throughout, the analysis reveals the way in which continuity and discontinuity within a tradition provide the conditions for later discovery and innovation.
\end{abstract}

\section{Introduction}

According to the manuscript tradition, John of La Rochelle (1190-1245) authored, and William of Melitona ${ }^{1}$ influenced, the questions on the sanctification of Mary found in the Summa Halensis. ${ }^{2}$ Following Alexander of Hales, they presented arguments informed by Anselm's concept of original justice, understood as a preternatural inclination toward rectitude in the will. This re-framing and re-casting of the essence of original sin used by Alexander of Hales represents an initial Franciscan shift away from (or nuancing of) the dominant Augustinian teaching in the direction of an Anselmian approach.

This shift enables a subsequent distinction between human nature and the person as it relates to the question of sanctification. And this distinction can be seen to influence the structural unfolding of the Summa's argumentation. In this way, a circular influence comes into view: a foundational shift in understanding results in the structural foregrounding of a key distinction that threads through the textual treatment and grounds the conclusion. But, oddly, despite these innovative elements, the conclusion does not depart (at least not yet) from the tradition.

So, despite their creative use of traditional authorities, the early Franciscans do not solve the question of Mary's immaculate conception. In fact, they deny it. Nonetheless, these early arguments and counter-arguments set the stage for the further

1 Franciscan Regent Master 1248-1255.

2 Allan B. Wolter, 'The Doctrine of the Immaculate Conception in the Early Franciscan School,' Studia Mariana 9 (1954): 26-69.

D OpenAccess. (c) 2020 Lydia Schumacher, published by De Gruyter. (c))BY-NC-ND This work is licensed under the Creative Commons Attribution-NonCommercial-NoDerivatives 4.0 License. 
development of the complete Franciscan solution that would be presented by John Duns Scotus $(1266-1308)$ at the turn of the $14^{\text {th }}$ century.

In what follows, we examine this early $13^{\text {th }}$-century Franciscan position on the Immaculate Conception. First, we present the basic argument offered by these early friars in Summa Book 3. ${ }^{3}$ Following this, we show how these arguments supported their denial of Mary's Immaculate Conception (although they defended her sanctification in utero). Finally, we consider the way in which the early foundations that supported their denial actually provided the conditions for the possibility of what would later become the definitive defense of the Marian prerogative, less than a century later.

Throughout, our analysis reveals the way in which continuity and discontinuity within a tradition provide the conditions for later discovery and innovation. Structurally as well as substantively, traditional arguments and authorities are made to play new roles in the development of a particularly Franciscan approach, even to complex theological questions such as this. Indeed, had the earlier Franciscan Masters not broken with the traditional Augustinian approach to original sin, its mode of transmission, and its effects, later thinkers such as John Duns Scotus would not have had such a well-developed foundation upon which to advance their arguments in favor of the Marian prerogative.

\section{The Argument in Favor of the Sanctification of Mary Found in the Summa Halensis}

Biblical texts refer to several important figures held by tradition to be sanctified prior to birth. Jeremiah ${ }^{4}$ and John the Baptist ${ }^{5}$ are the foremost among these. There is certainly a precedent for a question surrounding sanctification in the womb, especially in regard to Mary of Nazareth, who would become the mother of Jesus. Placing Mary's prerogative in the same category as Jeremiah and John was not in dispute. Setting her outside their category, however, would be problematic.

While belief in Mary's sanctification appeared in the West sometime during the Middle Ages, the feast itself has an ancient history in the East, as early as the $7^{\text {th }}$ century. Initially it was a Feast of St Anne, and only later shifted to focus on the 'mother

3 Alexander of Hales, Doctoris irrefragabilis Alexandri de Hales Ordinis minorum Summa theologica (SH), 4 vols (Quaracchi: Collegium S. Bonaventurae, 1924-48), Vol IV, P1, In1, Tr2, Q2, M2-3 (nn. 75-84), pp. 111-26. John of La Rochelle's special question, De sanctificatione beatae Virginis Mariae, was incorporated 'almost verbatim' into the Summa. See Wolter, 'The Doctrine of the Immaculate Conception,' 40, n. 64.

4 Jer. 1:5: 'Before you came to birth, I consecrated you.' (RSV)

5 Lk. 1:41: 'When Elizabeth heard Mary's greeting, the child leaped in her womb.' (RSV) 
of God'. ${ }^{6}$ Before the close of the $9^{\text {th }}$ century, it had become a universal feast of obligation in the Byzantine empire. ${ }^{7}$ It appeared in central Italy during the middle of the $9^{\text {th }}$ century. Irish martyrologies note the commemorations of Mariae Virginis Conceptio, celebrated on 2 or $3 \mathrm{May}^{8}$ These May feast dates make it difficult to see anything close to a continuous connection from Byzantine commemoration of the Marian feast to that of $11^{\text {th }}$-century England, when the feast of Our Lady's Conception was propagated in the West and fully recognized by the Bishops as part of the liturgy of the Church of England. ${ }^{9}$

With this background in mind, let us now turn to the text itself in the Summa Halensis. There the argument for Mary's sanctification unfolds according to five discrete questions, each focusing on a moment in the unfolding timeline of her development in the womb. The structure and organization of these questions represents a first and innovative 'mapping' of the timeline for sanctification. In this way, the analysis focuses on a deeper reflection of various moments within the womb: temporal instants at which her sanctification could take place. ${ }^{10}$ Each of these moments is analyzed according to its possibility for sanctification by divine intervention.

The question that guides the structure of the argument is this: 'if Mary's sanctification had occurred, when would it/could it have taken place?' The options are not many. If she were sanctified in utero, then it would have occurred at any one of five different moments in time. Each question takes up one of these moments:

a) A divine action before conception in the womb. Here, divine action would have involved cleansing both her parents, Anne and Joachim, from sin and from its effects so that they could have begotten a child and not passed on original sin.

b) A divine action at the moment of conception in the womb. Scholars distinguished between seminal conception and ensoulment (or animation). In other words, the flesh would have been cleansed prior to its union with the soul. This type of explanation would have involved divine intervention to prevent the libido-driven intercourse of her parents from causing the fleshly urge (stim-

\footnotetext{
6 Allan Wolter traces the careful doctrinal background in Wolter, 'Doctrine of the Immaculate Conception,' 26-7.

7 M. Jugie, 'Immaculée conception dans l'Église grecque après le Concile d'Ephèse,' in Dictionnaire de Theologie Catholique, vol. 7/1, ed. Jean Michel Alfred Vacant and Eugène Mangenot (Paris: Letouzey et Ané, 1922), 957, cited in Wolter, 'Doctrine of the Immaculate Conception,' 26.

8 H. Thurston, 'The Irish Origins of Our Lady's Conception Feast,' The Month 103 (1904): 449-65. 9 Francis M. Mildner, 'The Immaculate Conception in England up to the Time of John Duns Scotus,' Marianum 1 (1939): 91-2.

10 Marilyn McCord Adams, 'The Immaculate Conception of the Blessed Virgin Mary: A Thought-Experiment in Medieval Philosophical Theology,' Harvard Theological Review 103 (2010): 140: 'Even though none of these early Franciscans embraces the immaculate conception or even immaculate animation of the Blessed Virgin Mary, their further articulation of the consequences of Adam's fall for his descendants forwards the debate by explicitly mapping the points at which God might intervene to cleanse her.'
} 
ulus carnis) to be transmitted to her flesh. This could be understood as an immaculate, yet seminal, conception.

c) A divine action after conception and before ensoulment (animation by the rational soul). This points to the moment of mediate animation (the medieval understanding of ensoulment) when an already existing seminal material (zygote or embryo) is joined to the rational soul. ${ }^{11}$ For cleansing to have occurred at this moment, divine action would have to prevent, by an infusion of grace, the fleshly urge in her parents (stimulus carnis) from causing the tinder of sin (fomes peccati) in her. This could be understood as immaculate animation. ${ }^{12}$

d) A divine action at some moment between ensoulment and birth. Such a divine intervention would take place at some point during the development in the womb, by the infusion of cleansing grace into her soul. This explanation is similar to the cases of sanctification for Jeremiah and John the Baptist, traditionally described as sanctified before birth.

e) A divine action sometime after birth. This action ex utero would have taken place at some point prior to the virginal conception of Jesus.

Note how in all five of these scenarios, the centrality of sexual intercourse as sinful, the transmission of sin through intercourse, and the need for the cleansing of the flesh are all taken for granted. The stain of sinfulness and the need for cleansing testify to the lingering presence of Augustine's approach, despite the structural shift toward a more nuanced analysis of this issue.

So here we see Augustine's authority. And yet, far more is going on in this text than the appeal to tradition. In dealing with, and dismissing, three of the above five possibilities, John of La Rochelle makes use of a key distinction in his analysis that fundamentally alters the impact of Augustine. This key distinction is that between the sanctification of the person and the sanctification of the nature. ${ }^{13}$ The sanctification of nature refers to that nature we all share, passed down from one generation to the next through the act of sexual intercourse. The act of intercourse, which Augus-

11 Traditionally, this was held to be at 35 days for women and 42 days for men.

12 William of Melitona, in his more systematic analysis of the stages listed, actually raised the far more significant question: Whether she was sanctified at the moment the soul was infused? His question, taken from Quaestiones de sanctificatione B. Virginis (Toulouse, Bibliothèque Municipale 737, fols 36d-39a; see also Antonio Samaritani, 'La quaestio de sanctificatione B. Virginis di Guglielmo de Melitona,' Marianum 30 (1968), 161-80), not included in the Summa reveals what is at stake in the question of Mary's Immaculate Conception: the universal redemptive power of Jesus Christ. See Wolter, 'The Doctrine of the Immaculate Conception,' 41, n. 68.

13 SH IV, P1, In1, Tr2, Q2, M2, C1, Ar1 (n. 75), Solutio, p. 112: 'Dicendum quod duplex est sanctificatio, scilicet sanctificatio naturae et sanctificatio personae. Sanctificatio vero personae est per praesentem gratiam; sanctificatio naturae non erit nisi per futuram gloriam (...)' [It must be said that sanctification is twofold, namely sanctification of the nature and sanctification of the person. Indeed, sanctification of the person is through the presence of grace; sanctification of the nature will only take place in the future [state of] glory (...)]. 
tine identified as the carrier of original sin, was always tainted with concupiscence (fomes peccati), the source of sin. The sanctification of an individual, while possible through baptism, never extends beyond that person. We cannot inherit the effects of baptism from our parents. Consequently, absent the sanctification of human nature in general, all human generation is tainted with and transmits the guilt of sin and its consequences. The universal sanctification of human nature will only occur at the end of time, when the general resurrection takes place, glorifying the entirety of humanity.

By contrast, the sanctification of the person takes place in this life and is the result of ongoing divine grace. Here it is not only the individual nature, but the individual's will and the personal capacity for charitable actions that explains how such a sanctification is possible. Personal sanctification begins at baptism, when sanctifying grace cleanses the soul entirely. This restoration turns the soul back toward God. However, in spite of this cleansing and restoring action, remnants of sin remain in the person, specifically the human tendency toward evil (turning toward the things of the world) found in the inability of the higher rational powers to control the lower animal appetites and passions. Because of the differences in personal temperament, the effects of concupiscence vary from person to person. The source of these effects, original sin, does not vary.

This crucial distinction had its source in Anselm ${ }^{14}$ and is developed by Alexander of Hales ${ }^{15}$ and the tradition. ${ }^{16}$ Interestingly, John of La Rochelle does not reference Anselm in his use of this distinction. The distinction between the person and nature in need of sanctification is a development of Anselm's insight that, in Adam, a single human person contained the entirety of human nature. Because Adam was the only human being, he was in a class of beings of which he was the sole member. In him was the seed for the entire human race. In this way, as an individual person he corrupted his own nature; henceforth, the corrupted human nature would be passed on, corrupting all persons who come after.

14 Anselm of Canterbury, De conceptu virginali et originali peccato, c. 23 (PL 158:454 A-457B); Complete Philosophical and Theological Treatises of Anselm of Canterbury, trans. Jasper Hopkins and Herbert Richardson (Minneapolis: Arthur J. Banning, 2000), 456: 'As I have said, there is a sin which derives from a nature, and there is a sin which derives from a person. Thus, the sin which derives from a person can be called personal sin; and the sin which derives from a nature can be called natural sin. (It is also called original sin.) Now, just as the personal sin passes over to the nature, so the natural sin passes over to the person.'

15 Alexander uses this distinction in Alexander of Hales, Magistri Alexandri de Hales Glossa in quatuor libros Sententiarum Petri Lombardi II, d. 30, n. 7, 4 vols, Bibliotheca Franciscana Scholastica Medii Aevi, 12-5 (Quaracchi: Collegium S. Bonaventurae, 1951-7), 2:286-7, cited in Odon Lottin, Psychologie et Morale aux XIIe et XIIIe siècles, vol. 4/1, Problèmes de morale (Louvain: Abbaye du Mont César; Gembloux: J. Duculot, 1954), 171-2.

16 Lottin points to the important author of Douai, Bibliothèque Municipale, 434-II, 383b-388b, who develops the Anselmian distinction and uses it in various parts of his argument. See Lottin, Psychologie et Morale, 4/1:175. 
This distinction between sanctification of nature and sanctification of person threads through John of La Rochelle's entire argumentation in the Summa. In this way, the structure of the argument is itself influenced by the substantive distinction drawn initially from Anselm, but already developed in the Franciscan tradition. On the basis of the distinction, John's argument develops its own unique approach to defend what might be called the 'common solution'.

At this point, we can identify (at least) two important reasons that militated against a defense for the Immaculate Conception. The first reason would argue that, in order to be sanctified, one must be guilty of some impurity or sin. Even to speak of Mary's sanctification implies prior sin. So the question itself presupposes the need for sanctification. The second reason supported the first with the Augustinian teaching on original sin, namely its essential identification with concupiscence and its transmission via sexual intercourse. Since it is obvious that concupiscence remains even in the baptized person, it can be argued that, even with sanctification in the womb, there could be no conception or generation without the presence of sin.

In the first article (sanctification prior to conception), John affirms that Mary must have inherited sin from her parents, since she was conceived in the way that all humans are. ${ }^{17}$ Her nature is human nature. Therefore, she could not have been sanctified before her conception.

Thanks as well to this distinction, in the second article (sanctification at the moment of seminal conception), John argues that she could not have been sanctified at the moment of her conception. Here again, he reasons, in natural actions, nature is the mover while in personal actions, the will is the mover. While the will is capable of acting out of charity and thus performing a meritorious act (such as Abraham and Sarah, acting according to the divine command), the act of sexual intercourse follows nature's laws, and is, once again, tainted with concupiscence. This means that even the most laudable personal act of sexual intercourse still transmits original sin, due to the presence of concupiscence. ${ }^{18}$

17 SH IV, P1, In1, Tr2, Q2, M2, C1, Ar1 (n. 75), Solutio, 112: 'Propter hoc non est generatio sine peccato, quia natura non est sanctificata et per generationem transfunditur natura; ideo necesse est ut quod generatur, in generatione contrahat peccatum. Et propter hoc B. Virgo non potuit in parentibus suis sanctificari, immo necesse fuit quod in generatione sua contraheret peccatum a parentibus' [Because of this there is no generation without sin, because the [human] nature is not sanctified and the [human] nature is what is transmitted through generation; and so it is necessary that what is generated contracts the sin in [the act of] generation. And because of this, the Blessed Virgin could not be sanctified through her parents, because it was necessary that in her generation sin was contracted from her parents].

18 SH IV, P1, In1, Tr2, Q2, M2, C1, Ar2 (n.76), Solutio, p. 114: 'Supposito, quod alibi disputatur, quod coitus coniugalis possit esse meritorius, distinguendum quod est considerare coniugalem coitum meritorium secundum quod est actus personae vel naturae (...) Sed conceptio sequitur ad coitum et respicit naturam moventem, et non voluntatem' [Supposing that, as is disputed elsewhere, conjugal intercourse could be meritorious, one must distinguish between considering such conjugal inter- 
Likewise, in the third article (sanctification prior to ensoulment), John makes clear that flesh cannot be sanctified prior to ensoulment, since sanctification is only possible through divine grace, and the body is only able to receive grace when united to the soul. ${ }^{19}$

In the fourth article (sanctification in the womb), John confirms that, according to the distinction and the elimination of all other options, if Mary was sanctified in the womb, then this would have to have taken place after conception and ensoulment, and prior to natural birth. ${ }^{20}$

Finally, in a fifth article, John argues that Mary experienced a second sanctification, at the moment of the Annunciation, wherein her entire being (body and soul) was completely cleansed in order for her to conceive Jesus. Here we find a second moment of sanctification: importantly, this is a sanctification of nature, such that her flesh could unite with the Word..$^{21}$

Two questions can be raised at this point in our analysis. First, what is significant about this distinction between personal sanctification and the sanctification of human nature? Second, how does this distinction, understood as it is by these early Franciscan Masters, both promote and obstruct the later solution we find in the Franciscan tradition?

\section{The Significance of this Distinction for their Argument: Taking a Deeper Look}

The centrality of the distinction between sanctification of person and sanctification of human nature in the Summa Halensis indicates, first, how these early Franciscans have moved away from the mainline Augustinian position on original sin in order to take up Anselm's explanation of the essential nature of original sin and its relation-

course meritorious insofar as it is an act of the person or of the nature (...) But conception follows intercourse and is the result of a natural, not voluntary, movement].

19 SH IV, P1, In1, Tr2, Q2, M2, C1, Ar3 (n. 77), Solutio, p. 115: 'Dicendum quod caro ante animationem nullo modo potest sanctificari' [It must be said that in no way can the flesh be sanctified before animation].

20 SH IV, P1, In1, Tr2, Q2, M2, C1, Ar4 (n. 78), Solutio, p. 118: 'Concedendum est quod gloriosa Virgo ante suam nativitatem post infusionem animae in suo corpore fuit sanctificata in utero matris suae; et concendum etiam quod maiori dono gratiae fuit ditata quam aliquis alius' [It must be conceded that the glorious Virgin was sanctified in her mother's womb before her birth, after the soul's infusion in her body; and thus she was given an even greater gift of grace than any others].

21 SH IV, P1, In1, Tr2, Q2, M3, C1 (n. 80), Solutio, pp. 1212: 'In secunda vero sanctificatione fuit sanctificata in quantum potuit esse principium ad carnem aliam, et sic fuit sanctificata in quantum respiciebat naturam, et hoc ut de ipsa acciperetur caro unienda Verbo sine peccato (...)' [In the second [moment of] sanctification she was sanctified in such a way that she could be the source for another's flesh, and thus she was sanctified in [her human] nature so that the flesh uniting to the Verb be without $\sin (\ldots)]$. 
ship to concupiscence. In order to see this, let us consider how the distinction between sanctification of human nature and sanctification of the person reveals a deeper shift in the understanding of the essence of original sin.

For Augustine, the essence of original sin was concupiscence. That is, Augustine argued that the disordered and sinful act of Adam, whose punishment would be handed down through generations, was itself a disordered act of desire (concupiscence). The implication here is that, where concupiscence is present, there too is original sin. This also means that original sin is primarily due to disordered bodily desires, resulting in disobedience.

Anselm of Canterbury distinguished original sin from concupiscence, as cause from effect. Since all sin, he argued, is in the will, original sin is better understood as 'the absence of original justice' intended by God within the will. Because of this, disordered corporeal desires cannot explain the nature of Adam's sin, nor is concupiscence original sin. Rather, concupiscence is the effect or punishment that human nature inherits as a result of the lack of justice in the will. This effect, this punishment, is passed down through human generation, weakening the will and resulting in both an attraction to what is evil and a more difficult effort in doing what is good.

The distinction between personal sanctification and the sanctification of human nature, so central to the argument in the Summa, can be traced back to the argument of Anselm of Canterbury in his De conceptu virginali et originali peccato. ${ }^{22}$ It is derived from Anselm's discussion of free will as source for the first sin of Adam whose effects are transmitted to all humanity. In Adam all humanity has its source. Indeed, in Adam (and prior to the existence of any other humans) both human nature and the human person existed at one and the same time. After Adam, human nature is shared yet human personhood is individual.

Our will is free, affirms Anselm, due to the presence of two affections (or metaphysical orientations): the higher affection for justice (affectio iustitiae) and the lower affection for possession (affectio commodi). The higher affection, understood as the rectitudo voluntatis propter se servata (the will's self-conserving rectitude), is indeed the original justice intended by God. It was lost, both for the person and for the human race, as a result of Adam's sin.

In contrast to Augustine's explanation, Anselm understands original sin not as a positive entity or stain, but as a deficiency. Namely, the term 'original sin' refers to the absence or loss of this original justice, a natural (or, as Wolter terms it, preternatural) rectitude of the will as created and intended by God. This state of original justice can be understood as a preternatural (and not supernatural) inclination toward beatitude. Its loss occurred at the moment when Adam sinned. This fallen state is inherited by all descendants of Adam as a state of nature. It is this state that is in need of sanctification.

22 Anselm of Canterbury, De conceptu virginali et originali peccato, c. 23 (PL 158:454 A-457B), cited in Lottin, Psychologie et Morale, 4/1:14, n. 1. 
By contrast to the inherited sin of Adam, personal sin is also explained by free will. In Adam existed human nature and the human person. After Adam, human nature is shared among persons. The sin that derives from our shared nature (original $\sin$ ) is distinct from those sins which we commit (mortal and venial sins) and for which we alone are responsible.

Alexander of Hales and the early Franciscan masters inherited, defended and championed this Anselmian position on original sin, understood as an absence of original justice. But they also nuanced and integrated Anselm's theory with the historically and theologically more dominant Augustinian understanding of original sin, resulting in a far richer treatment of the nature of our present state, post lapsum.

Alexander presented original sin as involving two elements: 1 . the lack of original justice (from Anselm), and 2. concupiscence (from Augustine). The first holds the character of sin, and the second has the character of punishment, remaining behind even after baptism. Together, explains Alexander, they provide the dual aspect found in every sin: turning away from loving God (the unchanging Good) toward loving the things of the world (changing goods). ${ }^{23}$

As Alexander and the early Masters understood it, original justice refers to a preternatural quality or habit of the human will which, while free, was positively inclined to remain good. When this gift was lost through Adam's sin, the will of itself (de se) could incline toward sin. For the friars, the absence of original justice does not entail a positive inclination toward sin; it entails the loss of a positive inclination to remain good, resulting in a type of moral neutrality. They identified the positive inclination toward sin with concupiscence, the second element of, and punishment accompanying, original sin. The two inclinations of our present state, one a deficiency and the other positive attraction, point to the distinction between human nature and the individual person. While the loss of original justice is the same for all humans, concupiscence varies depending upon temperament.

The question surrounding Mary's sanctification now opens to two sub-questions, namely: 1. do the effects of sanctification remove the guilt of the sin itself or 2. do the effects of sanctification heal the consequences of the sin? More simply put: what, exactly, is sanctified in Mary that results in a privilege greater than that enjoyed by Jeremiah or John the Baptist?

23 Alexander of Hales, Quaestiones disputatae de peccato originali, cited in Wolter, 'The Doctrine of the Immaculate Conception,' 32, n. 39, which references the work by Lottin on Paris, Bibliothèque nationale de France, lat. 15272, fols 170vb-171ra and Paris, Bibliothèque nationale de France, lat. 16406, fol. 39va. See Lottin, Psychologie et Morale, 4/1:199-200. 


\section{How these Arguments Support Sanctification Without Affirming Immaculate Conception}

It is here that the earlier distinction between human nature and person helps to focus the question of the sanctification of the Blessed Virgin and explains the early Franciscans' hesitation to affirm the Marian privilege. As they understood it, if sanctification in the womb removes the guilt of the sin itself, then this would restore her human nature to its primal innocence. If, in addition, sanctification heals the consequences or effects of sin (concupiscence), then it seems that this would mean that the person, in his or her affective and voluntary condition, would be restored to the condition of inner harmony that was disrupted when the soul joined to the corrupted flesh.

Since the Franciscans' reasoning followed the tradition, in so far as the human nature would only be sanctified in eternal glory, they concluded that Mary's moment of sanctification could only have healed her affective and voluntary condition. It would have resulted in the re-establishment of the inner harmony enjoyed before the fall. This they were willing to admit. However, in order for her to belong to the human family, her sanctification could not have taken place except after an initial period of guilt. As John explains in Article $5,{ }^{24}$ the sanctification of her nature occurred at the Annunciation, enabling the Word to join with cleansed flesh. Mary would be completely sanctified only by the time she became the mother of Jesus. She could not be sanctified without a prior period of guilt.

The logical conclusion would be that only personal sanctification could apply, both to Mary before her birth, and to any baptized person. As these early Masters understood it, her human nature, inherited from her parents, guaranteed her solidarity with Adam and Eve in fallen humanity. Her personal sanctification, however complete, could not be inherited from her parents nor passed down from one generation to the next. And so, Mary was personally sanctified in the womb, like Jeremiah and John the Baptist, after ensoulment and prior to birth.

Two shifts have occurred. First, Anselm's position on original sin replaced a stain-based model with a deficiency-based model. Second, and importantly, this shift supported the more helpful distinction between sanctification of the nature and sanctification of the person. The first shift from Augustine to Anselm had indeed looked promising, insofar as it situated sin in the soul and the effects in the psychospiritual disharmony. It also emphasized how original sin is more properly understood as the absence of something, rather than the presence of something.

The second shift, however, actually reinforced the obstacle toward the defense of the Immaculate Conception. This obstacle lay in the continued identification of sin with its transmission through sexual intercourse as a positive stain upon human 
flesh and, consequently, as an infection of the soul. A positive reality (sin) was still understood as something to be inherited. Accordingly, in order to conceive of the Immaculate Conception, one would have had to imagine that Mary did not inherit or possess human nature as the rest of us do; her nature was sui generis. And this, of course, was unthinkable.

Despite the initial Alexandrian shift, these arguments offered by the early Franciscan masters continued to support the traditional 'sanctification before birth' position, denying the Immaculate Conception. Why is this? One obvious reason has to do with the dominant authority which Augustine continued to hold within the tradition. Tying the transmission of original sin to sexual intercourse as an act of concupiscence made it extremely difficult for these early Franciscans to distinguish between the essence of original sin (as a deficiency) and its consequences.

Indeed, the early Franciscans recognized the value of the second distinction (sanctification of nature vs. sanctification of person) without fully recognizing how it depended on the first shift surrounding the essential nature of original sin as the absence of original justice.

Alexander, in particular, had recognized the essentially spiritual character of 'the defect called original sin and the need of finding a moral cause for its existence as a fault in the unbaptized'. ${ }^{25}$ The moral cause for original sin, the fault to be cleansed in baptism, would then lie not in the flesh but in the way that the infected flesh interacts with the spirit at the moment of animation. This type of shift toward solidarity with Adam in our humanity, clearly a value for Franciscans, could promote the recognition that the consequences of Adam's fall have resulted in a particular weakening of the will at the very moment of ensoulment. As Alexander explains, persona corrumpit naturam, natura corrupta corrumpit personam. ${ }^{26}$

At the moment of animation, a rational soul is joined to the already 'fallen' or 'corrupted' human flesh, whose desires are disordered as a consequence of the inheritance from our first parents. That soul, now weakened by the desires of the flesh, is tainted with the disorder that results from a sin the person did not commit, but that belongs to human nature post lapsum. Our shared human nature is an act of solidarity with Adam. We inherit his debt (the absence of justice) and we share the punishments he earned in the same way that we would have shared his rewards, had he not sinned.

Accordingly, the consequences of the sin of our first parents are passed down through generations as punishment for a debt we inherit. These consequences are physical: they infect and weaken the soul at the moment it animates the body. They also survive in the disharmony of higher over lower appetites and passions.

25 Wolter, 'The Doctrine of the Immaculate Conception,' 37.

26 Alexander of Hales, Quaestiones disputatae de peccato originali (Nat. Lat. 15272, fol. 170va-vb; Nat. Lat. 16406, fol. 38rb-38vb), cited in Lottin, Psychologie et Morale,' 4/1:196: 'Person corrupts nature, corrupted nature corrupts the person.' 
As we attempt to see clearly what the early Franciscans understood about the Immaculate Conception, it is helpful to keep the following in mind:

1. These early Franciscan Masters embraced Alexander's shift toward the notion of original sin as the absence of original justice. Nevertheless, they continued to tie the transmission of original sin to sexual intercourse and libido.

2. While they mapped out the possibilities for sanctification as they relate to mediate animation (ensoulment), they did not focus the question on the exact moment when the soul is infused, and how, at that moment, divine grace could have been operative in protecting the soul from being infected by the tainted flesh. In other words, they do not yet appreciate the power of prevenient (or protective) grace. This action has less to do with removing a stain and more to do with removing an obstacle in order to allow the soul to function as it was meant to.

3. Consequently, they did not yet fully grasp how the shift from sin as a 'positive infection' to sin as 'the absence of original justice' would impact the development of a solution that could, in principle, defend a more radical position on the Immaculate Conception. Had they done so, they would have recognized how her soul might have been saved from the 'loss of original justice', thus ensuring the Marian privilege without sacrificing her humanity.

These early Franciscans are still conceptually under Augustine's shadow. Once the full implications of this shift from Augustine toward Anselm are more deeply understood, later Franciscan theologians will recognize the extent to which concupiscence is the effect of sin, rather than its essence. Concupiscence can now be logically separated from original sin, as an effect from its cause. This separation (even if only for a fraction of a moment in time) opens to a more significant distinction between the moment of conception (via carnal intercourse) and the inheritance of original sin by the soul upon its contact with the flesh. And this distinction will enable someone like John Duns Scotus to argue that Mary's immaculate conception can be considered independently of her human conception via intercourse. ${ }^{27}$

But the author of this text is not yet at this point of reflection. He still considers the immaculate conception to be ruled out, despite the Anselmian distinction he embraces. This is most evident in the second article, where he considers the sanctification of Mary at the moment of her conception. To understand what is at stake for him, let us consider more carefully this article.

27 Wolter, 'The Doctrine of the Immaculate Conception,' 37-8: 'Sanctifying grace will come to play a greater role than the iustitia naturalis in the interpretation of the formula 'carentia iustitiae debitae'. When this stage is reached, the fact that Mary was conceived by her parents through an act of carnal intercourse will no longer prove a stumbling-block to admitting her Immaculate Conception. Viewed from the history of the development of dogma, then, Alexander's speculations on the nature and mode of the propagation of original sin, though still far from satisfactory or adequate, represent a not insignificant indirect contribution to the theology of the Immaculate Conception.' 
The second article asks: Could the Blessed Virgin have been sanctified in her conception? The text of this question, the editors note, has its sources in the writings of William of Melitona and Odo Rigaldus. ${ }^{28}$ After a lengthy enumeration of the traditional pros and cons of this argument, primarily from Bernard of Clairvaux, ${ }^{29}$ the author presents a response, rather than a solution. The arguments against sanctification at the moment of seminal conception focus on three main points. First, only Jesus was conceived without sin. If one argues for Mary's immaculate conception, then one takes away from the preeminence of her son. Second, every act of intercourse is subject to libido. If one argues for Mary's immaculate conception, then one would deny that she was a member of the human race. Third, Church doctrine teaches that all have been redeemed in Jesus Christ. If one argues for Mary's immaculate conception, then one would have to exempt Mary, either because she is not redeemed or because she alone does not need redemption. These reasons will remain throughout the tradition as important counter-arguments to the immaculate conception.

In the response, the act of sexual intercourse is analyzed according to its natural (libido) dimension and its voluntary (potentially meritorious) dimension. For it to have been possible for Mary to have been conceived without sin, there would have needed to have been an act of intercourse completely free from any natural libido. In other words, something like a virginal insemination. This type of sanctification occurred at the annunciation and relates to the conception of Jesus in Mary's womb. Human conception such as with Mary, the author reasons, is always a 'commixed' act, with both natural and voluntary dimensions. The commixed nature of the act makes it impossible for it to be both natural and sanctified. Therefore, while Mary may have been sanctified at some point, it was not at the moment of conception.

Once again we see clearly how, despite 1. the shift from Augustine to Anselm in the definition of original sin and, following upon this, despite 2. the distinction between the domains of nature and person, the natural dimension of human intercourse remains dominant. This prevents a solution that would open toward viewing sanctification as possible at the moment of conception, whether identified with seminal conception, mediated animation or ensoulment. In other words, Augustine's position on the transmission of original sin via sexual intercourse is too authoritative to be dismissed or overruled.

As noted above, William of Melitona's consideration of sanctification the moment of ensoulment, while not included in the Summa, actually places the focus

28 William of Melitona, Quaestiones de sanctificatione B. Virginis Mariae (Toulouse, Bibliothèque Municipale 737, fols 37c-37d); Odo Rigaldus, In IV libros Sententiarum III, d. 3 (Brügge, Royal Library 208, fols 358b-359a), cited in SH IV, (n. 76), p. 113, n. 2.

29 Bernard's Letter to the Canons of Lyon affirmed Mary's holiness but denied her immaculate conception, on the grounds that it would extend to her mother, Anne, the privilege she alone held. Cf. Bernard of Clairvaux, Epistola 174 in S. Bernardi Opera, 8 vols, ed. Jean Leclercq, Charles H. Talbot, Henri M. Rochais (Rome: Editiones Cistercienses, 1957-77), 7:391-4; PL 182:335. 
squarely on the major obstacle to an argument in favor of the immaculate conception: if Mary were cleansed at the moment of her conception (whether seminal or animation), she would no longer be counted among those who owe their salvation to Jesus Christ. This objection confirms the tradition's position that in Jesus Christ all humanity is redeemed.

\section{Conclusions: The Franciscan status questionis and Conditions for the Possible Solution}

The early Franciscan treatment of the question of Mary's sanctification in the womb, while not departing from the common teaching, gives evidence of significant structural and methodological innovations. These innovations can mask the presence of Augustinian and Anselmian arguments, making it appear that these authorities have not been re-integrated into a new structure of argumentation. Indeed, a shift in structure and method here reveals the way in which traditional authorities are used in a new context, thereby giving rise to new understandings. These understandings, while not themselves giving birth to new solutions, provide the conditions for later thinkers to offer what would be known as the Franciscan solution to Mary's immaculate conception.

But this solution would be a generation away. In 1253, when Bonaventure incepted as Master, taking over from William of Melitona, the question of Mary's sanctification or immaculate conception had been clarified in the following important ways:

1. Franciscans accepted Anselm's teaching on original sin as the absence of original justice. They nuanced the post-lapsarian state, however, as one of moral neutrality - a loss of a positive inclination toward the good, rather than an inclination toward sin.

2. They give evidence of a growing understanding of the power of the distinction between original sin in its essence (as the absence of original justice) and in its effects (as concupiscence).

3. The early Masters had mapped out the various points of human development, moments at which the act of sanctification could occur. This was a structural innovation that would have substantive implications in subsequent thinkers.

4. In their analysis, Franciscans had shifted the emphasis of the question from conception to mediate animation (ensoulment, where soul and flesh unite).

5. William of Melitona had raised (elsewhere) the specific question of sanctification at the moment of animation. This would be the source for the defense of the immaculate conception (understood as mediate animation).

6. A final historical point needs mention. The celebration of Mary's conception was an important feast in England for Saxon Christians prior to the Battle of Hastings (1066). While the feast was suppressed under William the Conqueror, it was never eliminated, and Saxons continued to celebrate it, despite the restrictions. 
In 1129, the Council of London approved the celebration for the English province. The growing importance of such local piety, particularly in England, and the pastoral need to recognize what was happening in a local church, influenced Bonaventure who, while not approving the celebration of the Marian feast, saw no reason why the feast should be prohibited. ${ }^{30}$

All that was needed at this point in the development of doctrine was for someone to argue that sanctifying grace acted upon Mary's soul at the moment it came into contact with her (infected) flesh to cleanse it and protect it from losing the original justice intended by God, by means of prevenient grace. ${ }^{31}$ Such an act could be rationally defended in light of the role she would play in the history of salvation, as a type of retroactive effect of the graces won by Jesus Christ. This type of defense would still allow for the bodily effects of original sin (death, suffering, pain) which she did experience. What's more, her privilege could be even more strongly argued in terms of the intensity of grace she would have received, restoring in her the harmony of rational powers over lower appetites. Thus, not only is the sin prevented, but its consequences in her soul are also healed.

The gradual shifting and distilling of the various moves throughout this argument, both structural and substantive, from Augustine to Anselm, from the essence of $\sin$ to its consequences, from a more general question to one analyzed according to its temporal sequence, from the sanctification of nature to the sanctification of person, all demonstrate how within a given spiritual and theological tradition, continuity and discontinuity fuel the development of unthinkable solutions to what appear to have been unsolvable questions. By the time Alexander of Hales has been succeeded in the Chair in Paris, John of La Rochelle, Odo Rigaldus and William of Melitona have prepared the way for the innovations in the arguments of Bonaventure, William of Ware and John Duns Scotus.

30 Later, as Minister General, Bonaventure would introduce the celebration into the Franciscan order.

31 Allan Wolter shows the presence of an argument for the immaculate conception that Bonaventure himself cites in his Sentences. The author of this argument, most probably Norman or English, is unknown, but its presence in Bonaventure's text clearly demonstrates that, by mid-century, Franciscan thinkers are already anticipating the Scotist solution. See Wolter, 'The Doctrine of the Immaculate Conception,' 52-5. 
